\title{
НОВЫЕ ПРОИЗВОДНЫЕ МЕТИЛ [(5-МЕТИЛИДЕН-4- ОКСОЦИКЛОПЕНТ-2-ЕН-1-ИЛ)]АЦЕТАТА: ПОЛУЧЕНИЕ И ИССЛЕДОВАНИЕ ЦИТОТОКСИЧЕСКИХ СВОЙСТВ
}

\author{
Д.В.Ишметова', Л.Х. Зарипова', З.Р. Макаев², Ю.В. Вахитова', М.С. Мифтахов²
}

${ }^{1}$ ИБГ УФИЦ РАН, 450054, Россия, г. Уфа, проспект Октября, 71.

2УФИХ УФИЦ РАН, 450054, Россия, г. Уфа, проспект Октября, 71.

DOI: 10.19163/MedChemRussia2021-2021-481

E-mail:dikhas@mail.ru

С целью поиска активных аналогов соединения 1 в отношении ряда раковых клеток были синтезированы этаноламидное 3 и пропаргильное производное 4 метил [5-метилиден-4-оксоциклопент-2-ен-1-ил)]ацетата [1].<smiles>C=C1C(=O)C=C[C@@H]1CC(C)=O</smiles>

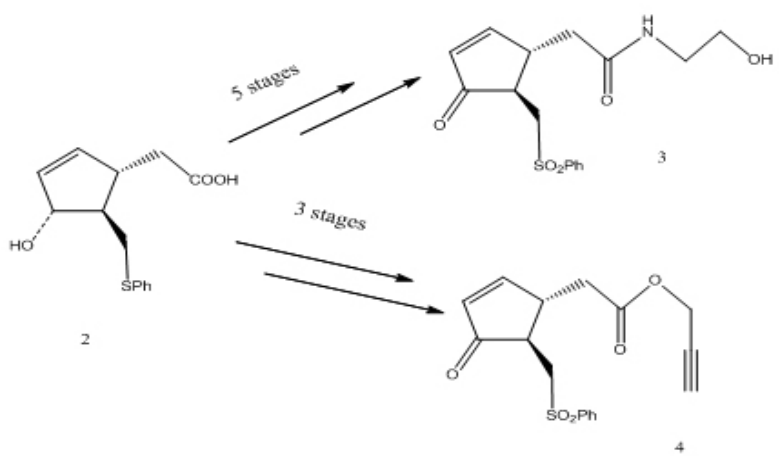

Из диенона 1 через ряд последовательных превращений получена гидроксикислота 2 , являющаяся ключевым промежуточным соединением в синтезе искомых производных.

Исследование цитотоксичности осуществляли путем анализа влияния веществ на жизнеспособность клеток линии НЕК293 (условно-нормальные эмбриональные клетки почки), SH-SY5Y (нейробластома), MCF-7 (аденокарцинома молочной железы), A549 (карцинома легкого) с помощью витального красителя PrestoBlue ${ }^{\circledR}$ invitro. Клетки инкубировали с соединениями в концентрации 1, 10 и 100 мкМ в течение 48 часов. Согласно полученным данным пропаргильное производное 4 проявляетцитотоксичность в отношении клеток нейробластомы (для SH-SY5YIC $=17,37 \pm 0,32$ мкM, для HEK293 IC $=65,22 \pm 6,34$ мкM). Этаноламидное производное 3 проявляет цитотоксичность в отношении всех клеточных линий (для HEK293 IC I0 $_{5}=23,16 \pm 5,33$ мкM, для SH-SY5YIC $=26,98 \pm 0,30$ мкM, для MCF-7IC $50=22,90 \pm 0,55$ мкМ, для $\left.\mathrm{A} 549 \mathrm{IC} \mathrm{C}_{50}=18,25 \pm 0,71 \mathrm{MкM}\right)$.

Работа выполнена в соответствии с планамигосзадания ИБГ УФИЦ РАН

№AAAA-A21-121011990119-1 и УФИХ УФИЦ РАН №AАAA-A20-120012090029-0.

$$
-481-
$$

